\title{
IIUM
}
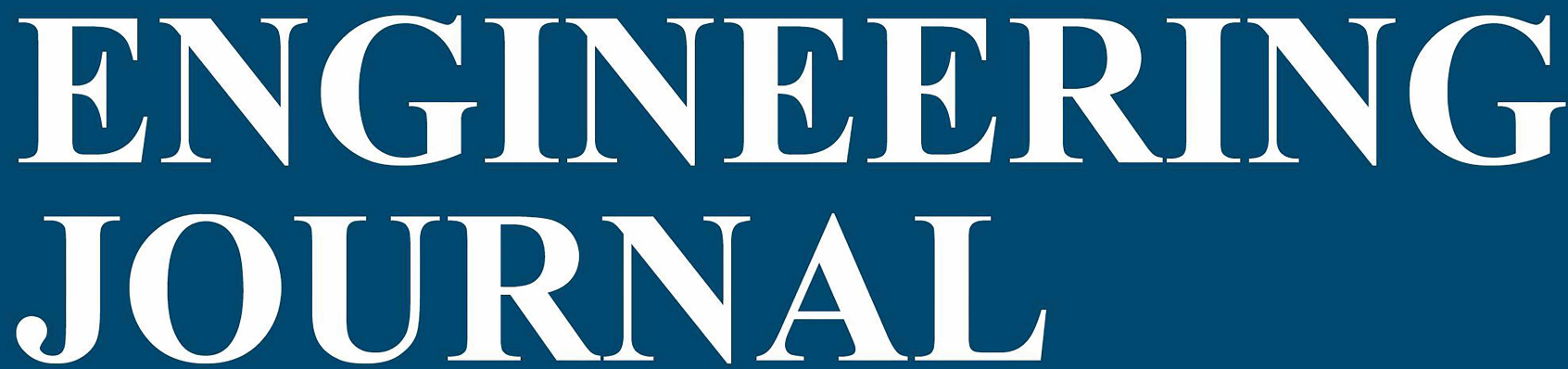

\section{Volume 22}

Number 1

January 2021

INTERNATIONAL ISLAMIC UNIVERSITY MALAYSIA

ISSN: 1511-788X E-ISSN: 2289-7860 http://journals.iium.edu.my/ejournal 


\title{
IIUM ENGINEERING JOURNAL
}

\section{CHIEF EDITOR}

Ahmad Faris Ismail, IIUM, Malaysia

\section{TECHNICAL EDITOR}

Sany Izan Ihsan, IIUM, Malaysia

EXECUTIVE EDITOR

AHM Zahirul Alam, IIUM, Malaysia

ASSOCIATE EDITOR

Nor Farahidah Za'bah, IIUM, Malaysia

LANGUAGE EDITOR

Lynn Mason, Malaysia

\section{COPY EDITOR}

Hamzah Mohd. Salleh, IIUM, Malaysia

\section{EDITORIAL BOARD MEMBERS}

Abdullah Al-Mamun, IIUM, Malaysia

Abdumalik Rakhimov, IIUM, Malaysia

Ali Sophian, IIUM, Malaysia

Erwin Sulaeman, IIUM, Malaysia

Hanafy Omar, Saudi Arabia

Hazleen Anuar, IIUM, Malaysia

Konstantin Khanin, University of Toronto, Canada

Ma'an Al-Khatib, IIUM, Malaysia

Md Zahangir Alam, IIUM, Malaysia

Meftah Hrairi, IIUM, Malaysia

Mohamed B. Trabia, United States

Mohammad S. Alam, Texas A\&M University-Kingsville, United States

Mustafizur Rahman, National University Singapore, Singapore

Ossama Abdulkhalik, Michigan Technological University, United States

Othman O Khalifa, IIUM, Malaysia

Razi Nalim, IUPUI, Indianapolis, Indiana, United States

Rosminazuin AB. Rahim, IIUM, Malaysia

Waqar Asrar, IIUM, Malaysia

\begin{abstract}
AIMS \& SCOPE OF IIUMENGINEERING JOURNAL
The IIUM Engineering Journal, published biannually (January and July), is a carefully refereed international publication of International Islamic University Malaysia (IIUM). Contributions of high technical merit within the span of engineering disciplines; covering the main areas of engineering: Electrical and Computer Engineering; Mechanical and Manufacturing Engineering; Automation and Mechatronics Engineering; Material and Chemical Engineering; Environmental and Civil Engineering; Biotechnology and Bioengineering; Engineering Mathematics and Physics; and Computer Science and Information Technology are considered for publication in this journal. Contributions from other areas of Engineering and Applied Science are also welcomed. The IIUM Engineering Journal publishes contributions under Regular papers and Invited review papers. It also welcomes contributions that address solutions to the specific challenges of the developing world, and address science and technology issues from an Islamic and multidisciplinary perspective.
\end{abstract}

\section{REFEREES' NETWORK}

All papers submitted to IIUM Engineering Journal will be subjected to a rigorous reviewing process through a worldwide network of specialized and competent referees. Each accepted paper should have at least two positive referees' assessments.

\section{SUBMISSION OF A MANUSCRIPT}

A manuscript should be submitted online to the IIUM-Engineering Journal website at http://journals.iium.edu.my/ejournal. Further correspondence on the status of the paper could be done through the journal website. 


\title{
INTERNATIONAL ADVISORY COMMITTEE
}

\author{
A. Anwar, United States \\ Abdul Latif Bin Ahmad, Malaysia \\ Farzad Ismail, USM, Pulau Pinang, Malaysia \\ Hanafy Omar, Saudi Arabia \\ Hany Ammar, United States \\ Idris Mohammed Bugaje, Nigeria \\ K.B. Ramachandran, India \\ Kunzu Abdella, Canada \\ Luis Le Moyne, ISAT, University of Burgundy, France \\ M Mujtaba, United Kingdom \\ Mohamed AI-Rubei, Ireland \\ Mohamed B Trabia, United States \\ Syed Kamrul Islam, United States \\ Tibor Czigany, Budapest University of Technology and Economics, Hungary \\ Yiu-Wing Mai, The University of Sydney, Australia.
}

Published by:

IIUM Press,

International Islamic University Malaysia

Jalan Gombak, 53100 Kuala Lumpur, Malaysia

Phone (+603) 6421-5014, Fax: (+603) 6421-6298

Whilst every effort is made by the publisher and editorial board to see that no inaccurate or misleading data, opinion or statement appears in this Journal, they wish to make it clear that the data and opinions appearing in the articles and advertisement herein are the responsibility of the contributor or advertiser concerned. Accordingly, the publisher and the editorial committee accept no liability whatsoever for the consequence of any such inaccurate or misleading data, opinion or statement.

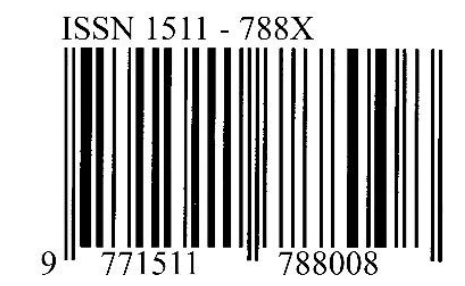

\section{IIUM Engineering Journal ISSN: 1511-788X E-ISSN: 2289-7860}




\title{
IIUM ENGINEERING JOURNAL
}

\author{
Volume 22, Issue 1, January 2021 \\ https:/doi.org/10.31436/iiumej.v22i1 \\ Table of Contents
}

EDITORIAL

\section{CHEMICAL AND BIOTECHNOLOGY ENGINEERING}

1447: A Novel Dimensionality Reduction Approach to Improve Microarray Data Classification 1 Mohammed Hamim, Ismail El Moudden, Mounir Ouzir, Hicham Moutachaouik and Mustapha Hain

\section{CIVIL AND ENVIRONMENTAL ENGINEERING}

1446: INFLUENCE OF FIBREgLASS MESH ON PHYSICAL PROPERTIES OF LIGHTWEIGHT FOAMCRETE Anisah Mat Serudin, Md Azree Othuman Mydin and Abdul Naser Abdul Ghani

1502: Froude Number Variance With Respect to the Hydrodynamic Response of a Non-Static Vehicle On a LoWLYING FLOODED ROADWAY 35 Syed Muzzamil Hussain Shah, Zahiraniza Mustaffa, Shabir Hussain Khahro, Khamaruzaman Wan Yusof, Ebrahim Hamid Hussein Al-Qadami, Aminuddin Ab Ghani and Fang Yenn Teo

\section{ELECTRICAL, COMPUTER AND COMMUNICATIONS ENGINEERING}

1276: Robust Tuning of Power System Stabilizer Parameters Using the Modified Harmonic Search Algorithm...47 Hiba Zuhair Abdul Kareem, Husam Hasan Mohammed and Ameer Aqeel Mohammed

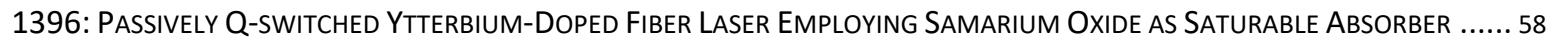
Khairul Nizam Rusdi, Afiq Arif Aminuddin Jafry, Nur Farhanah Zulkipli, Farina Saffa Mohamad Samsamnun, Mohamad Badrol Hisyam Mahyuddin, Sulaiman Wadi Harun, Mohd Shahnan Zainal Abidin and Norazlina Saidin

1495: Automatic FACIAl Redness Detection on FACE SKIn IMAgE Izzati Muhimmah, Nurul Fatikah Muchlis and Arrie Kurniawardhani

1532: IMPLEMENTATION OF A MACHINE LEARNING ALGORITHM FOR SENTIMENT ANALYSIS OF INDONESIA's 2019 PRESIDENTIAL ELECTION. 78 Ghulam Asrofi Buntoro, Rizal Arifin, Gus Nanang Syaifuddiin, Ali Selamat, Ondrej Krejcar' Herrera-Viedma and Hamido Fujita

1596: Monitoring ANd Control System With a Client-SerVer Model BASEd on INTERnet of Things (IOT) 93

Sri Ratna Sulistiyanti1, F.X. Arinto Setyawan, Sri Purwiyanti, Helmy Fitriawan and Adam Rabbani Adnan

1622: Predicting Trust in a Social Network Based on Structural Similarities Using a Multi-Layered Perceptron

NEURAL NETWORK.

Amir Hossein Danesh and Hossein Shirgahi

1814: Effect of Ferro Electric Thickness on Negative Capacitance Fet (NCFET)

Muhaimin Bin Mohd Hashim, Ahm Zahirul Alam Andnaimah Binti Darmis

\section{ENGINEERING MATHEMATICS AND APPLIED SCIENCE}

1389: FVS-TECHNOLOGY - INTELLECTUAL SEARCH TOOLS.... 118 Bahodir Muminov Boltayevich and Ulugbek Bekmurodov Bakhrom Ugli

1398: Solution of the ReVERSE Flow ReActor Model Using Homotopy ANALYSIS Method 129 Suharsono, Sri Wulandari, Aang Nuryaman, Mustofa Usman, Wamiliana and Jamal Ibrahim Daoud

1413: RELIABLE ITERATIVE METHOdS FOR SOLVING 1D, 2D AND 3D FISHER'S EQUATION...... 138 Othman Mahdi Salih and Majeed Ahmed. AL-Jawary

1497: ENERGY AND STRUCTURE STATES OF LOW-LYING BANDS IN ${ }^{156} \mathrm{GD}$

Pazlitdin Nuritdinovich Usmanov and Elmurod Kuchkarboyevich Yusupov

1520: Model DeVelopment of Ride Splitting Service With Resource Sharing Scheme on Ride Sourcing (OnLine TAXI)

SERVICES IN JAKARTA

Helen Burhan, Sutanto soehodho and Nary

1569: The HARMONIC COMPOSITION OF CURRENT IN ZERO-WORKIng WIRE WITH NON-LINEAR LOAD. 191 Igor V. Yudaev, Evgeny V. Rud, Mikhail A. Yundin, Tamara Z. Ponomarenko and Aleksandra M. Isupova 


\section{MATERIALS AND MANUFACTURING ENGINEERING}

1364: Characterisation and Melt Spinning of Poly (Lactic Acid)/Poly (Ethylene Glycol) Blends 201 Nur Atiqah Mohd Akhir, Maizatulnisa Othman, Yose Fachmi Buys and Sharifah Imihezri Syed Shaharuddin 1426: Graphene Oxide Microcapsules (GOMs) With LinSEed OIL CORE VIA PICKERING EMULSION Method: EFFECT OF DISPERSE SPEED.

Nurul Nadiah Sahir, Noor Azlina Hassan, Norita Hassan and Norhasnidawani Johari

1478: InVestigation on the MeChanical, Thermal, Bio-Degradation And Bio-Compatibility Properties of Poly (LACTIC ACID) / POLY (ETHYLENE GLYCOL) BLEND

Zohreh Zarinkolah, Hamed Bagheri, Saman Hosseinkhani and Maryam Nikkhah

1544: Preparation of CaO-Based Pellet Using Rice Husk Ash Via Granulation Method for Potential CO $_{2}$ Capture

Farah Diana Mohd Daud, Muhammad Mirza Mohamad Azir, Mudrikah Sofia Mahmud, Norshahida Sarifuddin and Hafizah Hanim Mohd Zaki

1548: Preparation of the Electrospun Polyvinylidene Fluoride / Polyvinyl Alcohol SCAfFold as a Potential TisSUe

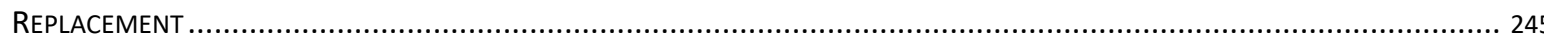

Mohd Syahir Anwar Hamzah, Nurul Amira Ab Razak, Celine Ng, Akmal Hafiszi Abdul Azize, Jumadi Abdul

Sukor, Soon Chin Fhon, Saiful Izwan Abd Raza and Nadirul Hasraf Mat Nayan

1587: The Durability of Hygro-IMmersion Aged Cellulose Fibre ReInforced Polymer LAyered Silicate

NANOCOMPOSITES.

C. S. Suhas Kowshik, Nanjangud Mohan, Nithesh Naik, Manjunath Shettar, Ritesh Bhat and

Shivaksh Rohatgi

\section{MECHATRONICS AND AUTOMATION ENGINEERING}

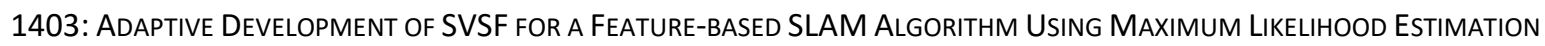
AND EXPECTATION MAXIMIZATION.... 269

Heru Suwoyo, Yingzhong Tian, Wenbin Wang, Long Li, Andi Adriansyah, Fengfeng Xi and Guangjie Yuan 1415: System of Automatic Control of the LeVel of Steam PoWer Generators on the Basis of the Regulation CIRCUIT WITH SMOOTHING OF THE SIGNAL.

Siddikov Isamiddin Xakimovich and Umurzakova Dilnoza Maxamadjonovna

1480: Assist as NeEded Control Strategy for UpPer Limb Rehabilitation Robot In EATING Activity 298 Norsinnira Zainul Azlan and Nurul Syuhadah Lukman

\section{MECHANICAL AND AEROSPACE ENGINEERING}

1538: Improved Constraint Handling Approach for Predictive Functional Control Using an Implied Closed-loop PREDICTION

Muhammad Abdullah, John Anthony Rossiter and Alia Farhana Abdul Ghaffar 